\title{
RESEARCH
}

Open Access

\section{Pink bollworm, Pectinophora gossypiella (Saunders) (Lepidoptera: Gelechiidae) survival on transgenic cotton in India}

V. Chinna Babu Naik* (D), Subbireddy KB, Sandhya Kranthi, V. S. Nagrare, Sujit Kumbhare, Nandini Gokte-Narkhedkar and V. N. Waghmare

\begin{abstract}
Background: Insecticidal proteins from the Bacillus thuringiensis (Bt) marks the genetically modified cotton crop that was commercialized in India in March 2002 for the control of lepidopteron bollworms. Despite organized initial control, the pink bollworm (PBW), Pectinophora gossypiella (Saunders), adapted itself to cry toxins resulted in field control failures in 2016 and 2017. The present study was designed to understand the survival and development of PBW populations differing in susceptibility to Cry toxins on Bt and non-Bt plants.

Results: For assessment of infestation, populations were collected from different cotton growing states. Per cent infestation of flowers and green bolls in the study areas were in the range of 3.09-29.26 and 36-91.20\% for flowers and green bolls, respectively. Among different locations highest magnitude of resistance to Cry1Ac (371.8-fold) and Cry2Ab (4214.3-fold) was spotted in late season populations of Rajkot collected from bolls. Further, in order to confirm field level resistance of surviving larvae on high and low concentrations of Cry toxins, larvae were pooled and subjected to boll bioassays. Results revealed that, none of the larvae from susceptible populations survived on BGIl bolls. Although, the same populations showed a survival of 38 and 32\%, which led to $80 \%$ locule damage on non-Bt cotton. Maximum survival (32\%) and locule damage (70\%) was observed for Maharashtra (F-H) Cry2Ab and Gujarat (B-H) Cry2Ab populations recorded 36\% survival and 70\% mortality, respectively, on BGIl cotton and 58.33\% survival and $60 \%$ locule damage on non-Bt cotton, respectively. Populations derived from survivals on low concentrations produced the lowest survival and locule damage on Bt cotton. Maximum number of mines on epicarp (2.4 mines/boll) was recorded by susceptible population on NBt cotton. Green bolls of Bt and NBt cotton did not differ in the number of mines.
\end{abstract}

Conclusion: It was concluded that none of the larvae from susceptible populations survived on BGll bolls. Although, the same populations showed a survival of 38 and 32\%, which led to $80 \%$ locule damage on non-Bt cotton

Keywords: Pectinophora gossypiella, Resistance, Bt cotton, Cry toxins and Bioassay

\footnotetext{
* Correspondence: chinnaenton@gmail.com

ICAR-Central Institute for Cotton Research, Nagpur 440010, India
}

(ㅇ The Author(s). 2021 Open Access This article is licensed under a Creative Commons Attribution 4.0 International License, which permits use, sharing, adaptation, distribution and reproduction in any medium or format, as long as you give appropriate credit to the original author(s) and the source, provide a link to the Creative Commons licence, and indicate if changes were made. The images or other third party material in this article are included in the article's Creative Commons licence, unless indicated otherwise in a credit line to the material. If material is not included in the article's Creative Commons licence and your intended use is not permitted by statutory regulation or exceeds the permitted use, you will need to obtain permission directly from the copyright holder. To view a copy of this licence, visit http://creativecommons.org/licenses/by/4.0/. 


\section{Background}

In cotton cultivation, bollworms are the major menace causing maximum yield losses since more than three decades. The pink bollworm (PBW), Pectinophora gossypiella (Saunders), is one of the key pests of cotton which damages the seeds and fiber thereby causing economic losses. Breakthrough came with introduction of Bt cotton that marked the first genetically modified crop commercialized in India, in March 2002. Subsequently, transgenic hybrids were developed by Maharashtra Hybrid Seed Company Limited using MON 531event carrying Bt gene, CrylAc. This gene offered protection against bollworm complex in cotton. Thereafter, Bollgard-II (Bt-cotton) was introduced in 2006, which contained stacked genes, Cry1Ac and Cry2Ab. The introduction of $B t$ cotton in India, the infestation levels of PBW, was under control. In 2010, PBW resistance to Cry1Ac was confirmed in four districts of Gujarat (Dhurua and Gujar 2011) the genetically based decreases in susceptibility of field populations of PBW to $B t$ toxins Cry1Ac and Cry2Ab. Studies conducted clearly indicated that the PBW developed resistance to cry toxins two deployed in BollgardII (Kranthi 2015; Naik et al. 2018). Laboratory selected strains in the USA survive on $B t$ cotton up to 3100-fold resistance to Cry1Ac (Tabashnik et al. 2008) and also 240-fold resistance to Cry2Ab (Tabashnik et al. 2009). After 12 years of commercial use in the USA, there are still no documented cases of resistance in Bollgard to any of three target pests (Moar and Anilkumar 2007). The development of resistance was accelerated in $P$. gossypiella against the Bt-toxins in the long duration $B t$-cotton hybrids that supported prolonged multiplication of multiple cycles of the pest. Increase in infestation of PBW in Bt cotton in recent years at several locations needs a thorough investigation to sustain the viability of transgenic technology for cotton crop protection.

The present study was designed to understand the survival and development of PBW populations differing in susceptibility to Cry toxins on $B t$ and non-Bt plants.

\section{Methods}

\section{Sample collections of pink bollworm}

Fields were sampled during 2017-2018 for PBW collection to quantify field infestation. Rosette flowers (infested flowers) and green bolls were collected from nine districts comprising four main cotton growing states in India viz., Andhra Pradesh, Telangana, Maharastra, and Gujarat. For this, unbiased random sampling was performed by selecting, on an average, five $B t$ cotton fields in a district. Damaged flowers were quantified by the ratio of the number of rosette flowers out of 25 flowers in 90 days old crop. Whereas, green boll damage indices was made by dissecting 25 bolls to record observations on the parameters viz., number of exit holes, mines on epicarp, surviving larvae (small white or large pink ones), and per cent locule damage. A total 150-200 green bolls ( 1 boll plant $\left.{ }^{-1}\right)$ were collected in a hectare on a 120-140 days old crop. Bolls from non-Bt cotton fields were also sampled wherever possible. These collected samples were dissected for larval recovery and multiplied by rearing on semi synthetic diet for further studies.

\section{Susceptibility of pink bollworm to Cry1Ac and Cry2Ab}

Few selected populations from flowers and bolls were subjected to bioassays using 21-day diet-incorporation assay as described (Muralimohan et al. 2009; Naik et al. 2018) by addition of stock solutions made from a freezedried commercial formulation of $\mathrm{MVP}^{\circ} \mathrm{II}^{\circ}$ (cell-cap ${ }^{\circ}$ Mycogen, USA) and lyophilized transgenic Bt-corn leaf powder with $6.8 \mathrm{mg} / \mathrm{g}$ Cry2 Ab protein. For diagnostic, assays concentration used were Cry1 Ac (10 ppm, $1 \mathrm{ppm}$, $0.1 \mathrm{ppm}, 0.01 \mathrm{ppm}$, and control) where in Cry $2 \mathrm{Ab}(5$ ppm, $1 \mathrm{ppm}, 0.1 \mathrm{ppm}, 0.01 \mathrm{ppm}$, and control). The multiple celled trays which contain approximately $\cong 1 \mathrm{~g}$ of the diet used in which freshly hatched neonate larvae were released at one larva per cell and the cells were sealed with a perforated transparent film. The trays were kept at $27 \pm 1{ }^{\circ} \mathrm{C}$, RH $60-65 \%$ under photoperiod of $9 \mathrm{~h}$ light and $15 \mathrm{~h}$ dark conditions. For every concentration, a total number of 16 larvae were released. Larvae that survived for at least the 4th instar after 21 days of feeding were considered as alive. Mortality corrections were calculated by Abbott's formula (Abbott 1925). Concentration-mortality regressions were calculated by probit analysis (Finney 1971).

\section{Resistant and susceptible strains}

Field populations recovered from flowers and green bolls were reared separately on semi-synthetic diet and in $F_{1}$ generation, 1-day-old neonates were exposed to log concentration probit assay with Cry1Ac and Cry2Ab toxins. Strains of each district from different fields that tolerated the highest concentration of toxins and survival at the end of 21 days were maintained by pooling larvae. Pooling was done to overcome insufficient cultures for continuing the study. The pooled populations were reared on diet with $B t$ cotton seed powder to sustain selection pressure. However, for the development of susceptible strain, larvae were reared continuously in laboratory for more than seven generations without any exposure to toxins. Laboratory susceptible strain of PBW is available at resistant monitoring laboratory (Insectary). Neonates in $\mathrm{F}_{2}$-resistant and susceptible strains were used for boll bioassays using 20-day-old green bolls on $B t$ and non- $B t$ plants in the field condition. 


\section{On-plant boll bioassays}

Further confirmation of resistance in PBW to cry1Ac and $\mathrm{Cry} 2 \mathrm{Ab}$ at diagnostic concentrations was performed by boll bioassays for the pooled resistant and laboratory susceptible populations by using Bt and non-Bt bolls on plant. The BGII hybrid and non-Bt cultivar Suraj were sown in an area of $13.2 \times 30 \mathrm{~m}$ at a spacing of $60 \times 60$ $\mathrm{cm}$ and $60 \times 10 \mathrm{~cm}$ for BGII hybrid and non-Bt respectively on the experimental farm. All the recommended agronomical practices were followed to raise the crop under rainfed condition. Resistant cultures from different locations and lab susceptible culture in the first instar were carefully released on $B t$ as well as non-Bt cotton bolls ( 1 boll/plant, a total of 5 bolls for each strain that was tagged on previous day) using a fine camel hair brush with 10 neonates/boll of resistant or susceptible cultures, respectively. The infested boll was covered with a butter paper bag whose mouth was properly sealed to avoid the escape of neonates from infested boll. After 21 days, the bagged bolls were collected and brought to the laboratory for observing PBW damage indices viz., number of mines on epicarp boll ${ }^{-1}$, per cent larval survival, and per cent locule damage boll ${ }^{-1}$.

\section{Results}

Flower and green boll infestation by early and late populations of PBW

The survey for PBW in $B t$ cotton was carried out in 2017-2018 season, in addition to previous surveys (2010-2014 in India) to understand the level of infestation and status of breakdown of resistance to cry toxins. The infestation of early populations on flowers in 71 fields (Table 1) was in the range of 3.09 to $29.26 \%$. Similarly, the per cent damage by late populations in 46 fields in Andhra Pradesh, Telangana, Maharashtra, and Gujarat was 36 to $90 \%$ variable. The highest per cent damage (91.20\%) was observed in Adilabad (Telangana) (south India). In Prakasam District of Andhra Pradesh, the damage was $83 \%$ across 4 locations. Similarly, in Maharashtra and Gujarat, damage was in the range of 56.60 to 79 and 36 to $90 \%$, respectively. The larval infestation on flowers was much lower than the infestation on bolls. Infestation on flowers across the four states ranged from 3.6 to $29.26 \%$.

\section{Concentration response in diet incorporation bioassays for Cry1Ac and Cry2Ab}

The initial resistance level in an early and late populations used in boll bioassay studies indicated (Table 2) the highest $\mathrm{LC}_{50}$ value of $1.859 \mu \mathrm{g} \mathrm{ml}^{-1}$ for late populations of Rajkot and the corresponding resistance ratio was 371.8-fold increase in Cry1Ac resistance. Resistance for Cry1Ac in early populations ranged from 1.4 to 26.4fold increase in resistance ratio, which was considerably less than the late populations derived from bolls. Likewise, the resistance for Cry2Ab was also the highest in late populations of Rajkot with $\mathrm{LC}_{50} 12.643 \mu \mathrm{g} \mathrm{ml}^{-1}$ and resistance ratio of 4214.33. Similar, to the early populations of Jalna which showed maximum resistance with $\mathrm{LC}_{50}$ value of $1.892 \mu \mathrm{g} \mathrm{ml}^{-1}$ and 630.67-fold increases in resistance. Remaining early populations documented resistance ratios in the range of 18.67 - to 67.67 -folds and $\mathrm{LC}_{50}$ value between 0.056 and $0.203 \mu \mathrm{g} \mathrm{ml}^{-1}$, the $\mathrm{LC}_{50}$ values for bioassays conducted with $\mathrm{F}_{1}$ progeny of early season populations of PBW from Rajkot, Junagadh, Amreli, Jalna, Wardha, and Yavatmal ranged from 0.007 to $0.132 \mu \mathrm{g} / \mathrm{g}$ of diet to Cry1Ac, while resistance ratio was the highest at 26.4. The $\mathrm{LC}_{50}$ for Cry1Ac to late season population $371.8 \mu \mathrm{g} / \mathrm{g}$ of diet.

\section{Boll bioassays}

The larvae that survived at high and low concentrations of $\log$ concentration probit assay for Cry1Ac and separately for Cry $2 \mathrm{Ab}$ were pooled in $\mathrm{F}_{1}$ generation and resistance was sustained by adding $B t$ cotton seed powder at $4 \mathrm{~g}$ per $70 \mathrm{ml}$ diet. Further confirmation of resistance

Table 1 Infestation of Pectinophora gossypiella on flowers and green bolls of Bacillus thuringiensis cotton in India

\begin{tabular}{llll}
\hline States & District & Pink bollworm damage indices & \\
\cline { 2 - 4 } & & Flower infestation (\%) & Green boll infestation (\%) \\
\hline Andhra Pradesh & Prakasham & $29.26(6)$ & $83(4)$ \\
Telangana & Adilabad & $9.15(18)$ & $91.20(5)$ \\
Maharastra & Wardha & $18.05(7)$ & - \\
& Yavatmal & $7.91(7)$ & $56.6(19)$ \\
& Jalna & $13.48(5)$ & $79(4)$ \\
Gujarat & Rajkot & $6.63(5)$ & $60(3)$ \\
& Junagadh & $3.09(6)$ & $69.60(5)$ \\
& Amreli & $3.6(7)$ & $90(2)$ \\
\end{tabular}

Note: Infestation of flowers and green bolls by field populations; the same populations which were survived on toxins log concentration probit assays was pooled in $F_{1}$ and boll bioassays was performed in field for further confirmation of resistance; figures in parenthesis are number of fields sampledss 
Table 2 Susceptibility of Pectinophora gossypiella to Cry1Ac and Cry2Ab

\begin{tabular}{|c|c|c|c|c|}
\hline \multirow[t]{2}{*}{ Locations } & \multicolumn{2}{|c|}{$\mu \mathrm{g} / \mathrm{g}$ of diet } & \multirow[t]{2}{*}{ Slope \pm SE } & \multirow{2}{*}{$\begin{array}{l}\text { Resistance } \\
\text { ratio }\end{array}$} \\
\hline & $\mathrm{LC}_{50}$ & 95\% fiducial limits & & \\
\hline \multicolumn{5}{|l|}{ Cry1Ac } \\
\hline Susceptible $_{141}$ & 0.005 & $0.0003-0.02$ & 0.4650 .157 & 1 \\
\hline Rajkot (F) & 0.018 & $0.00003-0.13$ & $0.422 \pm 0.176$ & 3.6 \\
\hline Junagadh (F) & 0.132 & $0.01-0.49$ & $0.839 \pm 0.274$ & 26.4 \\
\hline Amreli (F) & 0.016 & $0.0006-0.065$ & $0.681 \pm 0.228$ & 3.2 \\
\hline Jalna (F) & 0.028 & $0.0003-0.154$ & $0.599 \pm 0.236$ & 5.6 \\
\hline Wardha (F) & 0.007 & $0.00008-0.025$ & $1.031 \pm 0.437$ & 1.4 \\
\hline Yavatmal (F) & 0.017 & $0.0005-0.074$ & $0.706 \pm 0.244$ & 3.4 \\
\hline Rajkot (B) & 1.859 & $0.257-68.3$ & $0.424 \pm 0.173$ & 371.8 \\
\hline \multicolumn{5}{|l|}{ Cry2Ab } \\
\hline Susceptible $_{141}$ & 0.003 & $0.0001-0.013$ & 0.7660 .239 & 1 \\
\hline Adilabad (F) & 0.086 & $0.009-0.312$ & $0.624 \pm 0.221$ & 28.67 \\
\hline Prakasham (F) & 0.056 & $0.001-0.258$ & $0.535 \pm 0.214$ & 18.67 \\
\hline Wardha (F) & 0.203 & $0.028-1.043$ & $0.571 \pm 0.215$ & 67.67 \\
\hline Yavatmal (F) & 0.062 & $0.014-0.177$ & $0.864 \pm 0.256$ & 20.67 \\
\hline Jalna (F) & 1.892 & 0.399-192.42 & $0.522 \pm 0.224$ & 630.67 \\
\hline Rajkot (B) & 12.643 & $2.06-34502$ & $0.446 \pm 0.188$ & 4214.33 \\
\hline
\end{tabular}

Note: $F$ populations from rosette flowers, $B$ populations from bolls

in these survivals was verified by performing boll bioassay for their laboratory resistance and susceptibility on BGII hybrid and non-Bt cotton bolls in open field conditions to understand their survival and ability to cause boll damage. Number of mines on epicarp of bolls (Fig. $1)$, observed for of susceptible larvae $\left(\mathrm{F}_{141}\right.$ generation), was 0.80 and 2.40 mines per boll on $B t$ and non- $B t$, respectively. On the other hand, resistant populations of Maharastra (F-L) Cry1Ac made a maximum number of mines on epicarp (2.40 mines/ BGII boll). However, number of mines in other populations did not differ much for $B t$ and non-Bt cotton. Results presented in Table 3 revealed that not single larvae of the susceptible population survived on BGII cotton bolls that expresses

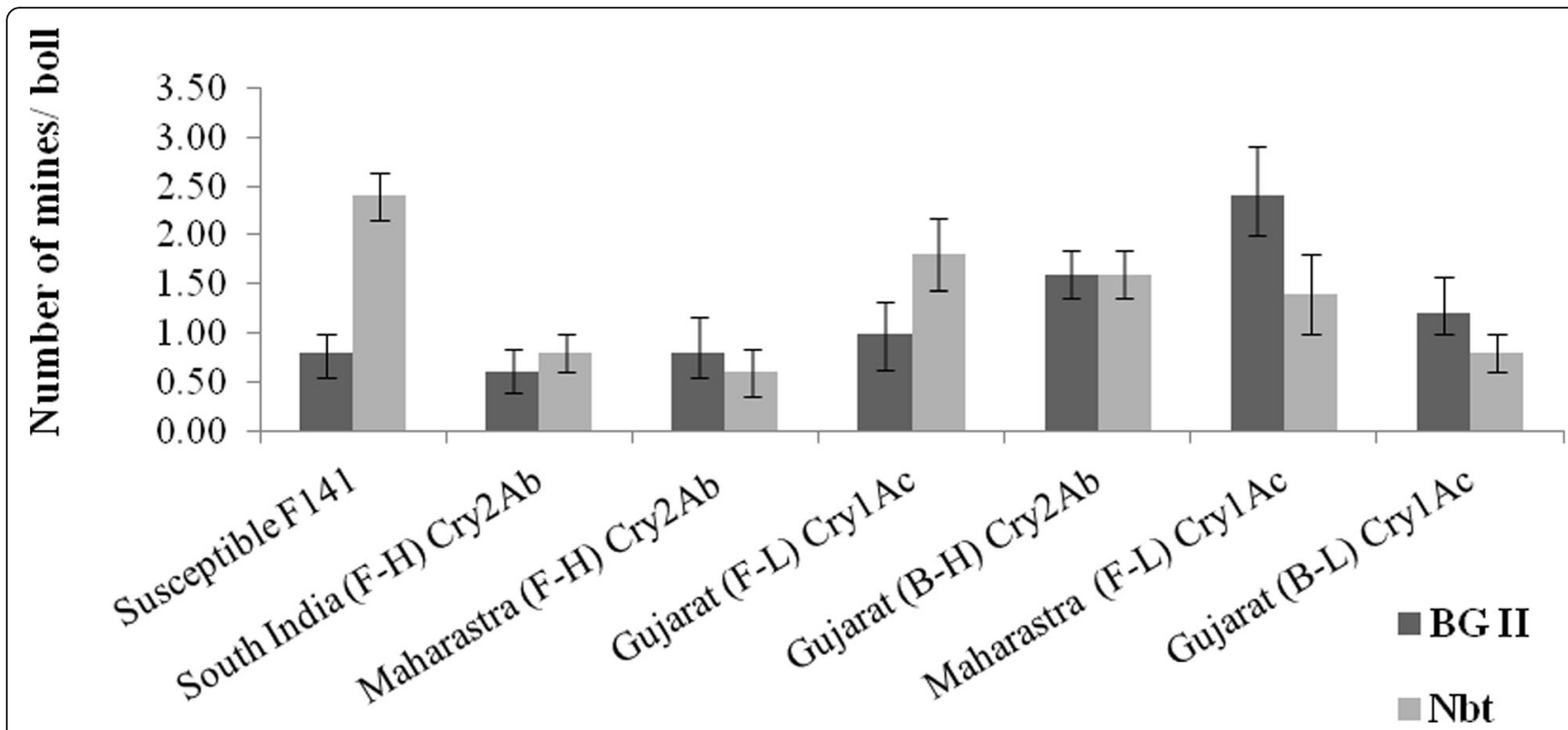

Fig. 1 Number of mines on epicarp damaged by susceptible and resistant strains of Pectinophora gossypiella to Cry toxins. Bar heights represent sample means, and error bars are the standard error of the mean 
Table 3 Survival of resistant and susceptible neonates of Pectinophora gossypiella on cotton bolls

\begin{tabular}{|c|c|c|c|c|}
\hline \multirow[t]{2}{*}{ Strains } & \multicolumn{2}{|c|}{ BG II [mean $\pm \mathrm{SE}(\mathrm{M})]$} & \multicolumn{2}{|c|}{$\mathrm{NBt}$ [mean $\pm \mathrm{SE}(\mathrm{M})]$} \\
\hline & $\begin{array}{l}\text { Larval survival } \\
\text { (\%) }\end{array}$ & Locule damage (\%) & $\begin{array}{l}\text { Larval survival } \\
\text { (\%) }\end{array}$ & Locule damage (\%) \\
\hline Susceptible $F_{141}$ & $0.00 \pm 0.00$ & $0.00 \pm 0.00$ & $38 \pm 3.74$ & $80 \pm 5.00$ \\
\hline South India (F-H) Cry2Ab & $24 \pm 4.00$ & $30 \pm 5.00$ & $24 \pm 4.00$ & $31.67 \pm 4.86$ \\
\hline Maharastra $(\mathrm{F}-\mathrm{H})$ CryzAb & $32 \pm 4.90$ & $70 \pm 12.25$ & $36 \pm 4.00$ & $58.33 \pm 5.27$ \\
\hline Gujarat (F-L) Cry1Ac & $28 \pm 4.90$ & $45 \pm 5.00$ & $24 \pm 4.00$ & $45 \pm 5.00$ \\
\hline Gujarat (B-H) Cry2Ab & $36 \pm 7.48$ & $70 \pm 5.00$ & $32 \pm 4.90$ & $60 \pm 6.12$ \\
\hline Maharastra (F-L) Cry1Ac & $24 \pm 4.00$ & $35 \pm 6.12$ & $28 \pm 4.90$ & $56.67 \pm 8.90$ \\
\hline Gujarat (B-L) Cry1Ac & $20 \pm 6.32$ & $29 \pm 5.34$ & $32 \pm 4.90$ & $68.00 \pm 10.56$ \\
\hline
\end{tabular}

$F$ populations from rosette flowers; boll bioassays were performed to confirm the survival of resistant and susceptible populations on $B t$ and non-Bt cotton in open field. $B$ populations from bolls; $H$ survivals on high concentration, $L$ survivals on low concentration, $S E$ standard error

Cry1Ac and Cry2Ab. Whereas, the same population survived up to $38 \%$ and indicated $80 \%$ locule damage on non-Bt cotton bolls. The highest survival of $36 \%$ on BGII bolls was accounted in the Gujarat (B-H) Cry2Ab population, followed by Maharashtra (F-H) Cry2Ab (32 \%). The populations of Gujarat derived from bolls and that survived at low concentration clearly showed the difference by showing low survival on BGII cotton bolls. Whereas, the highest survival of resistant population on non- $B t$ cotton was observed in Maharashtra (F-H) Cry2Ab which was $36 \%$. The per cent locule damage in green bolls infested by resistant populations seems to be the highest for the population of Maharashtra (F-H) Cry2Ab and Gujarat (B-H) Cry2Ab to the extent of $70 \%$, but the same populations caused low locule damage of 58.33 and $60.00 \%$, respectively, in non- $B t$ cotton. However, the populations derived from survivals on low concentrations produced low locule damage to the magnitude of 29.00 to $45.00 \%$ on $B t$ cotton. All strains larvae surviving high and low toxins concentrations, representative of geographical location recorded larval survival ranging from 20 to $36 \%$ and locule damage of $29-70 \%$ on BGII green bolls. On non- $B t$ green bolls, larval survival ranged from 24 to $36 \%$ and locule damage ranged from 31 to $68 \%$. The susceptible strains recorded larval survival and locule damage of zero per cent on BGII green bolls and 38 and $80 \%$ on non- $B t$ green bolls. The larvae that survived both high and low concentrations of the crylAc and Cry2Ab toxin in the $F_{1}$ generation sourced from flower or bolls caused mines on the epicarp and survived on bolls and caused locule damage as seen in boll bioassays on BGII and non-Bt. The lab susceptible strain causes mines, damages locules, and survives on non- $B t$ bolls while they caused 2.4 mines on the boll epicarp, $80 \%$ locule damage, and $38 \%$ larval survival on non- $B t$ bolls.

\section{Discussion}

The present work was carried out to understand the survival of PBW on $B t$ and non- $B t$ cotton. The PBW survival was first reported in a small patch of Gujarat in 2010 after 8 years of introduction of $B t$ cotton in India (Dhurua and Gujar 2011). Subsequent studies from Monsanto in 2010 confirmed resistance in PBW to Cry1Ac. The propensity of PBW to evolve resistance to Cry1Ac has already been reported (Bartlett 1995; Tabashnik et al. 2006). Minimum infestation of flowers by early populations of PBW in present study is in accordance with the earlier reports (ICAR-CICR Annual Report 2015-2016, 2016-2017). The larval recovery from bolls or flowers in south and central India is more or less similar (Naik et al. 2018). Similarly, the green boll damage observed in present study was not very different from that in south and central India. More or less similar findings were reported by the following researchers (Mohan et al. 2016; Kranthi 2015; ICAR-CICR Annual Report 2016-2017). The PBW infestation to Bollgard continued in Gujarat, and many Bollgard fields in the adjoining states of Maharashtra and Madhya Pradesh showed high-level infestation by the pest (Mohan et al. 2016; Naik et al. 2017). The infestation of green bolls in different districts of Maharashtra, Gujarat, and Andhra Pradesh on different BGII hybrids ranged from 8 to 98 , 64-72, and 35-96\%, respectively (ICAR-CICR Annual Report 2016-2017). Increase in locule damage in the Raichur area of Karnataka from 44.8\% during 20012002 to $62.6 \%$ in 2004-2005 has been recorded by Patil et al. (2007). Previous surveys conducted from 2012 to 2014 reported significantly high survival of PBW on BGII. Previous studies conducted clearly showed that PBW developed resistance for two cry toxins deployed in Bollgard-II (Kranthi 2015; Naik et al. 2018). Toxicity of Cry2Ab against neonates of $P$. gossypiella $\left(\mathrm{LC}_{50} 0.051\right.$ $\mu \mathrm{g} \mathrm{ml}^{-1} ; \mathrm{MIC}_{50} 0.028 \mu \mathrm{g} \mathrm{ml} \mathrm{g}^{-1}$ ) that was nonsignificantly different from Cry1Ac (Muralimohan et al. 
2009). Laboratory selected Cry2Ab PBW populations caused up to 420-fold cross-resistance to Cry1Ac, as well as 240-fold resistance to Cry2Ab (Tabashnik et al. 2009). Resistance to the tune of 18,000 - to 150,000 -fold increase was observed to Cry2Ab in strain Bt4-R2 after only 2 generations of laboratory selection (Fabrick et al. 2015). In the present study, a huge increase in resistance was observed in late season populations of PBW from Rajkot to both Cry1Ac and Cry2Ab, when compared to early population. The differences could be speculated to be due to early population being weak and sensitive to cry toxins compared to late populations. Earlier workers have observed that normally expression intensities and efficacy of PBW infestation observed high during early growth stages and have shown declined in later crop growth stages (Greenplate 1999; Kranthi et al. 2005b; Olsen et al. 2005). Kranthi et al. (2005a) also reported a gradual decline in the level of Cry1Ac at 110 days after sowing with respect to the age of the plant. Results of boll bioassays conducted in present study is concomitant with results of previous study by Tabashnik et al. (2002) in greenhouse bioassay. Cry1Ac resistant PBW strain survived equally well on transgenic cotton with Cry1Ac and on cotton without Cry1Ac. Survival on $B t$ cotton relative to that on non- $B t$ cotton was $40 \%$ (3.1\% on $B t$ cotton with Cry1Ac versus $7.8 \%$ on non- $B t$ cotton) (Tabashnik et al. 2002). However, resistant strain from Gujarat (B-H) Cry2Ab in the present study survived and damaged on $B t$ cotton bolls when compared to non- $B t$ cotton. It might be due to the strain representing survival on Cry2 $\mathrm{Ab}$ high concentrations and possess strong resistance. Mutations in a gene encoding a cadherin protein that binds $B t$ toxin Cry1Ac are associated with field-evolved resistance of PBW to Cry1Ac produced by transgenic cotton in India (Fabrick et al. 2014). Release on non- $B t$ cotton bolls hampered the survival and ability to cause damage reveals fitness costs involved in the strain that needs further examination. Increased resistance to Cry1Ac might be due to favorable conditions, involving the quality of cotton plants or other environmental factors that may tend to reduce the difference in survival between non- $B t$ and $B t$ cotton with Cry1Ac for resistant larvae (Tabashnik et al. 2002). Minings on epicarp were similar on $B t$ and non-Bt cotton bolls, and this is in accordance with Liu et al. (2002), where they reported that mining was affected by boll age and diameter, not due to $B t$ toxin in bolls. The results clearly indicated PBW resistance to Cry1Ac and Cry2Ab in India has already reached peaks. In order to sustain cotton production, it was necessary to find efficient alternatives to overcome this serious problem that needs strict implementation of certain the simplest and most potent management strategies such as taking up of timely sowing and cultivated early maturing short- duration genotype to escape field infestation. All other management strategies such as late season pyrethroids spray, use of semio chemicals, pheromone traps, bio pesticides, biological control, removal of cotton stalks immediately after third picking of cotton the animal grazing of harvested fields and destruction of ginneries waste that need to be followed in a community-based approach (Naik et al. 2018). Such strategies would be helpful in breaking insect life cycle during off seasons. The strategies developed can be replicated in other affected cotton growing states to contain loss caused by pink bollworm in collaboration with state agricultural department, state agricultural universities, and other stakeholders.

\section{Conclusion}

Results revealed that none of the larvae from susceptible populations survived on BGII bolls. Populations derived from survivals on low concentrations produced the lowest survival and locule damage on $B t$ cotton. Maximum number of mines on epicarp was recorded by susceptible population on NBt cotton. Resistant strain from Gujarat (B-H) Cry2Ab in the present study survived and damaged $B t$ cotton bolls when compared to non-Bt cotton.

\section{Supplementary Information}

The online version contains supplementary material available at https://doi org/10.1186/s41938-021-00393-7.

Additional file 1: Supplementary Table 1. Pooled populations of surviving larvae on log dose assay for Cry1Ac and Cry2Ab from different locations.

\section{Abbreviations}

Bt: Bacillus thuringiensis; PBW: Pink bollworm; BGll: Bollgard II; $\mu \mathrm{g} /$ g: Microgram per gram; SE: Standard error; LC: Lethal concentration; MIC: Moult inhibitory concentrations; MON: Monsanto company; F: Populations from rosette flowers; B: Populations from bolls; $\mathrm{H}$ : Survivals on high concentration; L: Survivals on low concentration; n: Number of insects pooled

\section{Acknowledgements}

We thank our team at pink bollworm resistance monitoring laboratory for rearing of field collected pink bollworm, maintenance of resistant and susceptible populations as well as assistance for boll bioassays. Authors are also grateful to Director, ICAR-CICR, Nagpur for providing all necessary facilities for this study. Financial support by DST-SERB-EMR, Ministry of Science and Technology, India, is gratefully acknowledged.

\section{Authors' contributions}

VN designed and achieved planning of experiments and wrote the manuscript. SB carried out the experiments. SK and VN have done analysis of the data. SK had done sample collection for the experiment purpose. NG and W helped in planning of the experiment and critically revised the article. The authors read and approved the final manuscript.

\section{Funding}

The project was funded by Ministry of Science of the Republic of India. Department of

Science and Technology, Science and Engineering Research Board (SERB) under extramural

research (EMR) funding scheme. 
Availability of data and materials

Not applicable.

\section{Ethics approval and consent to participate}

Not applicable.

\section{Consent for publication}

Not applicable.

\section{Competing interests}

The authors declare that they have no competing interests.

Received: 1 October 2020 Accepted: 17 February 2021

Published online: 24 February 2021

\section{References}

Abbott WS (1925) A method of computing the effectiveness of an insecticide. J Econ Entomol 18(2):265-267

Bartlett AC (1995) Resistance of the pink bollworm to Bt transgenic cotton. In: Proceedings Beltwide Cotton Conferences, pp 766-768

Dhurua S, Gujar GT (2011) Field-evolved resistance to Bt toxin Cry1Ac in the pink bollworm, Pectinophora gossypiella (Saunders) (Lepidoptera: Gelechiidae), from India. Pest Manag Sci 67:898-903

Fabrick JA, Ponnuraj J, Singh A, Tanwar RK, Unnithan GC (2014) Alternative splicing and highly variable cadherin transcripts associated with field-evolved resistance of pink bollworm to Bt cotton in India. PLoS One 9:e97900

Fabrick JA, Unnithan GC, Alex J, Yelich AJ, DeGain B, Masson L, Zhang J, Carrière $Y$, Tabashnik BE (2015) Multi-toxin resistance enables pink bollworm survival on pyramided Bt cotton. Scientific Reports 5:16554

Finney DJ (1971) Probit Analysis, 3rd edn. Cambridge University Press New York, NY 10022:333

Greenplate JT (1999) Quantification of Bacillus thuringiensis insect control protein Cry1Ac over time in Bollgard cotton fruit and terminals. J Econ Entomol 92: 1377-1383

ICAR-CICR Annual Report, 2015-2016. http://www.cicr.org.in.

ICAR-CICR Annual Report, 2016-2017. http://www.cicr.org.in.

Kranthi K, Dhawad C, Naidu S, Mate K, Patil E, Kranthi S (2005a) Bt cotton seed as a source of Bacillus thuringiensis insecticidal Cry1Ac toxin for bioassays to detect and monitor bollworm resistance to Bt-cotton. Curr Sci 88:796-800

Kranthi KR (2015) Pink bollworm Strikes Bt-Cotton. Cotton Statistics and News. No.35

Kranthi KR, Naidu S, Dhawad CS, Tatwawadi A, Mate K, Patil E, Bharose AA, Behere GT, Wadaskar RM, Kranthi S (2005b) Temporal and intra-plant variability of Cry1Ac expression in Bt-cotton and its influence on the survival of the cotton bollworm, Helicoverpa armigera (Hübner) (Noctuidae: Lepidoptera). Curr Sci 89:291-298

Liu YB, Tabashnik BE, Dennehy TJ, Carrière Y, Sims MA, Meyer SK (2002) Oviposition on and mining in bolls of Bt and non-Bt cotton by resistant and susceptible pink bollworm (Lepidoptera: Gelichidae). J Econ Entomol 95:143148

Moar WJ, Anilkumar KJ (2007) The power of the pyramid. Science (Wash DC) 318: 1561-1562

Mohan KS, Ravi KC, Suresh PJ, Sumerford D, Head GP (2016) Field resistance to the Bacillus thuringiensis protein Cry1Ac expressed in Bollgard ${ }^{\circledR}$ hybrid cotton in pink bollworm, Pectinophora gossypiella (Saunders) populations in India. Pest Manag Sci 72:738-746

Muralimohan K, Kamath SP, Mohan KS, Ravi KC, Deeba F, Sivasupramaniam S (2009) Mass rearing diet for the pink bollworm Pectinophora gossypiella (Lepidoptera: Gelechiidae) and its susceptibility to insecticidal Bt proteins. Int J Trop Insect Sci 29:102-107

Naik VC, Kranthi S, Kumbhare S, Nagrare VS (2017) A manual on pink bollworm resistance monitoring and management. ICAR-Central Institute for Cotton Research, Post bag no.2, Shankar Nagar, Nagpur-440010 pp-36

Naik VC, Kumbhare S, Kranthi S, Satija U, Kranthi KR (2018) Field evolvedresistance of pink bollworm, Pectinophora gossypiella (Saunders) (Lepidoptera: Gelechiidae) to transgenic Bt-cotton expressing Cry1Ac and Cry2Ab in India. Pest Manag Sci. https://doi.org/10.1002/ps.5038

Olsen K, Daly J, Holt H, Finnegan E (2005) Season-long variation in expression of Cry1Ac gene and efficacy of Bacillus thuringiensis toxin in transgenic cotton against Helicoverpa armigera (Lepidoptera: Noctuidae). J Econ Entomol 98 1007-1017
Patil BV, Bheemanna M, Hanchinal SG, Hosamani AC, Bansi AB (2007) Status of pink bollworm, Pectinophora gossypiella (Saunders) on cotton at Raichur, Karnataka. J Cotton Res Dev 21:224-226

Tabashnik BE, Biggs RW, Fabrick JA, Gassmann AJ, Dennehy TJ, Carriere Y (2006) High level resistance to Bacillus thuringiensis toxin Cry1Ac and cadherin genotype in pink bollworm. J Econ Entomol 99:2125-2131

Tabashnik BE, Gassmann AJ, Crowder DW, Carriére Y (2008) Insect resistance to $B t B t$ crops: evidence versus theory. Nat Biotech 26:199-202

Tabashnik BE, Timothy J, Dennehy SMA, Larkin K, Head GP, Moar WJ, Carrière Y (2002) Control of resistant pink bollworm (Pectinophora gossypiella) by transgenic cotton that produces Bacillus thuringiensis toxin Cry2Ab. Appl Environ Microbiol 68:3790-3794

Tabashnik BE, Unnithan GC, Masson L, Crowder DW, LiX CY (2009) Asymmetrical cross-resistance between Bacillus thuringiensis toxins Cry1 Ac and Cry2Ab in pink bollworm. Proc Natl Acad Sci USA 106:11889-11894

\section{Publisher's Note}

Springer Nature remains neutral with regard to jurisdictional claims in published maps and institutional affiliations.

\section{Submit your manuscript to a SpringerOpen ${ }^{\bullet}$ journal and benefit from:}

- Convenient online submission

- Rigorous peer review

- Open access: articles freely available online

- High visibility within the field

- Retaining the copyright to your article

Submit your next manuscript at $>$ springeropen.com 